\title{
Os Direitos Humanos como Produto: reflexões sobre a informação e a cultura da mídia
}

\author{
Fábio Souza da Cruz ${ }^{1}$ \\ Marcelo Oliveira de Moura ${ }^{2}$
}

\begin{abstract}
Resumo: Este artigo traz reflexões sobre algumas problemáticas envolvendo a mídia tradicional e a questão dos Direitos Humanos na atualidade. Adotando uma postura crítica, histórica e dialética, o trabalho faz uma intersecção entre os veículos de comunicação de massa tradicionais e os Direitos Humanos, com o propósito de problematizar questões sobre ambos e apontar possíveis saídas. Para tanto, dentre outros autores, foram utilizados os pressupostos desenvolvidos por Roland Barthes (1971), Joaquín Herrera Flores (2005) e Douglas Kellner (2001). Salienta-se que não se pretende generalizar resultados a partir de uma pesquisa bibliográfica, mas, sim, detectar tendências e vislumbrar possibilidades a respeito da temática em pauta.
\end{abstract}

Palavras-chave: Mídia. Direitos Humanos. Globalização Neoliberal.

\begin{abstract}
In this article, we discuss some problems involving the traditional media and the human rights nowadays. Adopting a critical, historical and dialectical approach, the paper makes an intersection between the traditional mass media and the $\mathrm{DH}$ in order to discuss issues on both subjects and pointing out possible alternatives. In order to carry out the study, the theories of Roland Barthes (1971), Joaquín Herrera Flores (2005) and Douglas Kellner (2001) are taken into consideration. It is important to stress that the intention of this paper is not to generalize results from our bibliographical research, but to detect tendencies and discern trends about the topic under discussion.
\end{abstract}

Key words: Media. Human Rights. Neoliberal Globalization.

1 Possui Pós-doutorado em Direitos Humanos, Mídia e Movimentos Sociais pela Universidade Pablo de Olavide - Sevilha/Espanha. Doutor em Cultura Midiática e Tecnologias do Imaginário pela PUC-RS. Professor do Programa de Pós-Graduação em Política Social e do curso de graduação em Comunicação Social da Universidade Católica de Pelotas (UCPel).E-mail: fabiosouzadacruz@gmail.com.

2 Doutorando e Mestre em Direito pela Universidade do Vale do Rio dos Sinos (UNISINOS/RS). Professor de Direito Penal, Criminologia e Introdução ao Estudo do Direito na Universidade Católica de Pelotas (UCPel) e Coordenador do Programa de Estudos de Direito Constitucional e Direitos Humanos do Curso de Direito da UCPel. E-mail: mardmoura@hotmail.com.

Recebido em: 15/12/2011.

Revisado em: 12/03/2012.

Aprovado em: 20/08/2012. 


\section{Introdução}

Como nos alerta Zygmunt Bauman, o grande problema da condição contemporânea de nossa civilização moderna é que ela parou de questionar-se. O resultado de nosso conformismo/indolência é pago

[...] na dura moeda do sofrimento humano. Fazer as perguntas certas constitui, afinal, toda a diferença entre sina e destino, entre andar a deriva e viajar. Questionar as premissas inquestionáveis do nosso modo de vida é provavelmente o serviço mais urgente que devemos prestar aos nossos companheiros humanos e a nós mesmos. (BAUMAN, 1999, p. 11)

Esse espírito é o incentivo na construção deste artigo, ou seja, vai projetado na perspectiva de formulação de questionamentos, de provocação, de disseminação de angústia e desconforto quanto à possibilidade de responder às demandas sociais contemporâneas mediante uma percepção do jurídico e social, orientada por operações cognitivas simplificadoras.

Entretanto, como projeto de crítica, ele encerra compromisso com uma postura afirmativa de oposição que "[...] no puede quedarse en la deconstrucción, una vez que ésta, llevada al extremo, cumple el papel de deconstruir la propia posibilidad de resistencia y de alternativa" (SANTOS, 2003, p. 34). Assim, neste texto, pretende-se trabalhar vinculado a uma política de afirmativas que permita critérios capazes de viabilizar uma releitura da realidade. Dessa maneira, solicita-se que nos permita criar problemas; problematizar a realidade avaliando; e estabelecer novos pontos de partida para a reinvenção, a ressignificação das formas tradicionais de conhecimento jurídico e social forjados pela modernidade ocidental.

Nesse sentido, apoiado no arsenal teórico de Joaquín Herrera Flores, sustenta-se que a (re)construção faz-se desde uma visão de afirmação da diferença, que não reduz a realidade ao existente-dado ou posto, e busca avançar num viés de abertura de espaço de novas possibilidades, com a tarefa crítica de interpretação ou (re)significação da natureza e de construção de um âmbito de alternativas ao que está dado, ou hegemoni- 
camente definido no que tange aos Direitos Humanos, aos movimentos sociais e ao papel da mídia tradicional nesta realidade.

Compreende-se, portanto, que não há um princípio único de transformação social, vários futuros alternativos são possíveis (SANTOS, 2003 , p. 34). Resta, conscientes, também, que são grandes as dificuldades de tecer uma abordagem crítica na contemporaneidade frente ao fato de que os problemas vinculados aos déficits modernos transformam-se em problemas para os quais não parece haver solução. Todavia, o fato de "[...] nos enfrentarmos a problemas modernos para los cuales no hay soluciones modernas [...]" (SANTOS, 2003, p. 30), por nós é tomado como desafio e, mais ainda, como uma imposição ética de solidariedade com as vítimas da injustiça, opressão e exclusão.

\section{Visões Tradicionais acerca dos Direitos Humanos, Movimen- tos Sociais e a Luta pela Garantia da Dignidade}

No debate que envolve a justificação e a fundamentação dos Direitos Humanos, no âmbito da ciência jurídica, é possível encontrar fundamentalmente duas visões imperantes:

1) uma visão abstrata, vazia de conteúdo, referenciada nas circunstâncias reais das pessoas e centrada na concepção ocidental de direito e do valor da identidade;

2) uma visão localista, na qual predomina o "próprio", o nosso, com respeito ao dos outros, e centrada na idéia particular de cultura e de valor da diferença. (HERRERA FLORES, 2004, p. 364)

Duas perspectivas teóricas que determinam tipos de racionalidade e de práticas diferenciadas: a) visão abstrata, racionalidade formal e prática universalista; e b) visão localista, racionalidade material-cultural e práticas particulares; as quais, no entanto, se aproximam em sua tendência à unitariedade,

[...] supõem sempre se situar em um centro de onde se passa a interpretar todo o restante. Nesse sentido, torna-se a ser a mesma coisa 
analisar uma forma de vida concreta ou uma ideologia jurídica e social. Ambas funcionam como um padrão de medidas e de exclusão. Dessas visões deriva um mundo desintegrado. (HERRERA FLORES, 2004, p. 366)

Enfim, nas duas está presente um recorte da realidade a partir do qual se constroem práticas de dominação de todos os espaços que não se completam. Assim, pode-se perceber que tanto as visões abstratas como as localistas abominam o contínuo fluxo de interpretações e de reinterpretações. Cada uma, por seu lado, procura colocar um ponto final hermenêutico que determine a racionalidade em suas análises e propostas (HERRERA FLORES, 2004): o universalismo fecha-se numa expansão contínua e o particularismo/localista enclausura-se em uma contração permanente. (SÁNCHEZ RÚBIO, 2000)

Nesse sentido, pode-se observar que a visão localista/particularista se afoga frente à pluralidade de interpretações e, a seu modo, ainda constrói outro universalismo, um universalismo de retas paralelas que somente encontraram-se no infinito do magma das indiferenças culturais. (HERRERA FLORES, 2004)

O localismo sistematiza seu próprio "ponto final" sob as premissas de uma racionalidade material que resiste ao universalismo colonial, a partir dos pressupostos do "próprio". Fecha-se sobre si mesmo. Resistindo a uma tendência universalista a priori de depreciar as "distinções" culturais, com objetivo de impor uma só forma de ver o mundo, o localismo reforça a categoria da distinção, de diferença radical, com o que, em última instância, acaba defendendo uma visão abstrata do mundo: a separação entre nós e eles, o desapreço pelo outro, ignorância sobre o que nos faz idênticos e a relação com os outros; a contaminação de alteridade. (HERRERA FLORES, 2004, p. 373)

Isso conduz à prática que respeita as diferenças, mas torna absoluta a identidade, postura que esconde, como diz Herrera Flores (2004), as relações hierárquicas - dominantes/dominados. Esse particularismo radical, como afirma Sánchez Rubio (2000, p. 233/234): 
[...] entre otras cosas se le critica el hecho de que cuando valora de la misma manera a todas las culturas, lo hace ya desde un criterio universal de respecto a todos los grupos particulares. También al supeditar al individuo libre y autónomo a las normas y los hábitos dictadas por la comunidad, se le está anulando su capacidad de decidir libremente y rebelarse frente a las injusticias cometidas por la colectividad. Además, excluye criterios para contrastar y distinguir las sociedades totalitarias de las sociedades democráticas. Finalmente, la esencialización de la comunidad, la etnia, la raza o la nación, es fuente de marginación y discriminación de todo aquello que queda fuera de su círculo de pertenencia. Se conforma un nosostros excluyente frente a los despreciados.

Por outro lado, o fechamento operado pela hegemônica visão abstrata, que predomina no âmbito acadêmico e alicerça as práticas da maioria das "bem intencionadas" pessoas e organizações que lutam pela garantia dos Direitos Humanos, dá-se mediante uma "racionalidade formal" que carrega efeitos extremamente perversos. Mediante um processo que consiste em redução da

[...] racionalidade à coerência interna de regras e princípios, a visão abstrata dos direitos esquecerá algo muito importante para o entendimento da sociedade e dos direitos: regras e princípios reconhecidos juridicamente estarão submetidos às exigências de coerência e falta de lacunas internas. Mas, por sua vez, essa racionalização do real, em termos jurídicos, não terá em consideração a "irracionalidade das premissas" sobre as quais se sustentam e as quais pretendem conformar desde sua lógica e sua coerência. (HERRERA FLORES, 2004, p. 371)

Os Direitos Humanos ficam, assim, reduzidos aos seus componentes jurídicos, sendo que a luta por dignidade resta confinada ao espaço judicial. Ocorre um fenômeno de aprisionamento dos Direitos Humanos pela lei. Adverte-se, desde já, que consideram-se indispensáveis os embates no âmbito judicial, porém, reduzir a luta a este locus leva a um aceite da racionalidade interna e da irracionalidade das premissas que subjazem as estruturas institucional-normativas. (HERRERA FLORES, 2004, p. 372) 
Não se pode negar a profunda vinculação de nossas declarações de Direitos Humanos e das instituições - de âmbito nacional e internacional - com competência para tratar essas questões, com um projeto político liberal-burguês e individualista e sua lógica da acumulação do capital e do benefício privado, em que não há espaço considerável para a satisfação das necessidades elementares das pessoas.

Assim, a visão universal e sua racionalidade formal - retirando a impureza histórica dos Direitos Humanos - avança numa perspectiva descontextualizada no tempo e no espaço e tem nos levado a um olhar contemplativo das relações de poder. Ocultando as causas reais das desigualdades e, como se pode ver, sustentando a expansão irrestrita de acumulação de capital em tempos de globalização orientada pela agenda neoliberal, universalizando todo um fundamento ético-político liberal e individualista.

Nesse panorama, inserem-se as leituras correntes acerca do Direito, do papel da sociedade e dos movimentos sociais na luta pela garantia da dignidade que se constroem desde uma lógica descontextualizada, à margem do sistema de relações que constituem suas condições de existência.

Convém referir que "[...] no transcurso da história, o Estado (Moderno) viu-se envolto em um largo processo de consolidação e transformação passando, nos dias de hoje, por uma longa desconstrução/exaustão [...]" (MORAIS, 2002, p. 12), o que se reflete de forma peculiar nos países periféricos, de origem colonial, em que o "ente estatal" sempre se prestou aos interesses externo-metropolitanos.

Como nos alerta Herrera Flores, a nova fase da globalização, a denominada neoliberal, tem como uma das características fundamentais a proliferação de centros de poder (o poder político nacional se vê obrigado a compartilhar "soberania" com corporações privadas e organismos globais multilaterais ${ }^{3}$ ). Assim, percebe-se que frente ao processo de globa-

\footnotetext{
3 A título ilustrativo, como nos alerta Bolzan de Morais (2002, p. 28-29), verifica-se no referente às organizações econômicas supranacionais que "[...] não se pode olvidar o papel jogado pelas chamadas empresas transnacionais no bojo de um capitalismo financeiro que, exatamente por não terem nenhum vínculo com um Estado em particular e, mais ainda, por disporem de um poder de decisão, em especial financeiro, que pode afetar profundamente
} 
lização instrumentalizado a partir de um discurso neocapitalista, a instituição central da modernidade - o Estado-Nação - é colocada em xeque. (HERRERA FLORES, 2004)

O Estado não mais figura como locus privilegiado de poder. Em tempos de globalização, vive-se o momento de superfragilização estatal. Como afirma Bauman (1999, p. 71-72), os três pés - militar, econômico e cultural - que formam o "tripé da soberania" foram quebrados sem esperança de conserto. De agente que reivindicava o direito legítimo e que ostentava recursos suficientes para estabelecer e impor as regras e as normas que ditavam o rumo dos negócios num certo território, ou seja, que ambicionava impor certo modelo de ordem preferido em vez de outros alternativos, o "ente estatal" dá lugar a novos atores - forças anônimas - transnacionais produtores de ordem opressiva. Tais forças instituem originais espaços decisórios - novos sítios legislativos, executivos e jurisdicionais -, estabelecendo lugares e formas diferenciadas de dominação e tirania.

Portanto, vive-se um tempo de surgimento de "Novos Leviatãs", o que permite afirmar que o "[...] tirano contemporâneo não é mais representável no Estado, nem na maioria eleitoral, nem numa classe. Não há mais lugar institucional específico que substancialize o poder [...]”, sendo essa invisibilidade talvez um dos maiores desafios das organizações políticas contemporâneas. (AGUIAR, 2004, p. 250)

Essas novas dinâmicas "[...] que sacrificam a democracia no altar do mercado e a justiça ao invés do lucro [...]” (BORON, 1998 p. 33), têm gerado efeitos específicos nos países que ocupam posição periférica na estrutura geopolítica mundial. As consequências nefastas do referido processo, nestes ambientes particulares, superdimensionam-se comprometendo o já escasso coeficiente democrático - aqui medido a partir da efetiva garantia daqueles que o Ocidente convencionou chamar Direitos Humanos - dos países de modernidade tardia.

a situação de muitos países, especialmente aqueles débeis economicamente, superposto a um modelo produtivo de novo tipo onde a produção cede lugar à auto-reprodução do capital, adquirem um papel fundamental na ordem internacional e, em especial, impõem atitudes que não podem ser contrastadas sob o argumento da soberania estatal". 
Nesse contexto, de novas formas de dominação/tirania que se abatem de forma especial sobre as vítimas dos países "eufemisticamente" chamados de "nações em desenvolvimento", emerge a exigência de um (re)pensar das balizas abstracionistas e idealizadoras de compreensão dos Direitos Humanos.

As justificações produzidas dessa categoria jurídica, na sua maioria, fundamentadas a partir de visões liberais-contratualistas, perdem consistência neste novo cenário de redistribuição do poder. Os novos processos que surgem no mundo globalizado estão exigindo uma nova perspectiva teórica e política no que concerne aos Direitos Humanos, e pondo em questão a natureza individualista, essencialista, estatalista e formalista dos direitos que marcam as construções até a última década do século XX. (HERRERA FLORES, 2004)

Mais do que isso, os processos de vitimização e opressão das populações periféricas revelam fundamental uma atualização do debate referente às estratégias de resistência levando-se em consideração os movimentos das vítimas e num viés de resgate da dignidade dos discursos filosófico-jurídicos dos mundos que hoje se situam na periferia. (DUSSEL, 2002)

As construções abstratas, como se viu, amarram os institutos jurídicos ao espaço estreito da relação indivíduo-Estado, sendo que os Direitos Humanos somente existem nesta lógica marcada pelas camisas de força impostas pelas premissas mercadológicas subjacentes a toda construção.

Tem-se clara a importância das Declarações de Direitos, conforme se disse anteriormente, e inclusive das leituras tradicionais, entretanto, insiste-se na sua insuficiência e nos seus aspectos paradoxais insuperáveis. Nesse sentido, ratifica-se que

A mera judicialização de direitos esquece que as normas jurídicas e os tribunais constituem um subsistema do corpo político e que, por isso, resultam débeis ou forçosamente limitados ante a "razão do Estado" que se orienta a reproduzir assimetrias como condição de 
uma dominação (econômica-social e cultural) que supõe e produz discriminações. (GALLARDO, 2000, p. 39)

Nesse cenário apresenta relevância o papel jogado por aqueles que no âmbito social, a partir de discursos alternativos, escapando das amarras universalista e formalista dos Direitos Humanos, lutam pela transformação das estruturas de poder e alteração das formações sociais e políticas. Os movimentos populares e sociais, desde suas lutas por melhores condições de vida e acesso aos bens que garantem dignidade, oferecem um novo arsenal de fundamentação capaz de superar os limites das teorias anteriormente expostas.

Destarte, é forçoso admitir a importância dos movimentos sociais como fonte geradora de produção jurídica que proporcionam uma contaminação do direito por elementos que encontram vínculo radical com as demandas da sociedade. Rompendo com a percepção monista-estatalista, pode-se visualizar quiçá uma real democratização do jurídico, garantindo o protagonismo para os reais detentores do "direito de criar o direito", a sociedade e os seres humanos concretos.

\section{A Mídia como Palco de Disputas}

Definitivamente, hoje, os meios de comunicação consistem nos principais agentes de mediação da sociedade em tempos de globalização. Por meio de textos e imagens, a cultura midiática corrobora, assim, para um fortalecimento dos laços sociais ao mesmo tempo que fornece elementos de homogeneização de discursos e identidades.

Nesse sentido, a mídia constrói mitos e estereótipos, sugere regras, modas e hábitos. Por trás desse véu sedutor, ela busca audiência e, consequentemente, lucros cada vez maiores. Para isso, lança mão de uma mistura de elementos oficiais com outros artifícios nem sempre palatáveis como, por exemplo, o fait divers ${ }^{5}$.

4 Tradução livre de fragmento da obra de Gallardo (2000).

5 Informação sensacionalista. Os "casos do dia" ou "fatos diversos" refletem o capitalismo contemporâneo que, através dos seus significados e métodos, fornece 
Fomentando uma memória curta e efêmera, o fait divers reflete algumas das premissas da era globalizante: as informações devem ser líquidas e, ao mesmo tempo, atingir o emocional das pessoas. Assim, as relações dessa categoria, criada por Roland Barthes (1971), são constituídas pelo excepcional e pelo grotesco que valorizam o espetacular e podem ser reduzidas em dois tipos básicos: causalidade e coincidência. Ambos apresentam subtipologias respectivas, direcionadas para a compreensão da excepcionalidade, da condição do estabelecimento e da noção de conflito.

O fait divers de Causalidade revela dois tipos: a causa perturbada, quando se desconhece, ou não é possível precisar a causa, e, ainda, quando uma pequena causa provoca um grande efeito; e a causa esperada, em que, quando a causa é normal, a ênfase desloca-se para a "dramatis personae" (personagens dramáticos), como, por exemplo, crianças, mães e idosos. (BARTHES, 1971, p. 267-271)

$\mathrm{Na}$ causa perturbada, ocorrem fatos excepcionais, espantosos, que implicam perturbação e conflito. Há um efeito (o conflito surge daí). No entanto, a causa é desconhecida, imprecisa, ou, até mesmo, ilógica, sem sentido. Não obstante, uma pequena causa pode provocar um grande efeito. Há uma riqueza de desvios causais. Devido a certos estereótipos, espera-se uma causa e surge outra, mais pobre do que a esperada. Nesse gênero de relação causal, há o espetáculo de uma decepção; paradoxalmente, quanto mais escondida, mais notada será essa causalidade.

Barthes (1971, p. 271-274) divide o fait divers de coincidência em dois tipos: de repetição - quando a informação repetida leva a imaginar causas desconhecidas, que ocorrem em circunstâncias diferentes - e de antítese, quando se aproximam dois termos qualitativamente distantes. A antítese une dois termos opostos, como se nunca tivessem sido, estabelecendo a noção de conflito, disponibilizando a emocionalidade. Em cada termo, pertencendo a um percurso autônomo de significação, a relação de coincidência apresenta, como função paradoxal, fundir dois percursos diferentes em um percurso único.

elementos que tendem a relegar os indivíduos à passividade e à manipulação ao mesmo tempo que obscurece a natureza e os efeitos do poder vigente. 
Passando à frente de instituições como, por exemplo, a família, a escola e a igreja, os meios de comunicação adquirem caráter centralizador na atualidade. Nessa realidade, eles atuam em compasso com as forças hegemônicas da sociedade. Considerando isso, percebe-se que a ideologia $^{6}$ transmitida pela mídia nesse caso "[...] é [geralmente] a do branco masculino, ocidental, de classe média ou superior; são as posições que vêem raças, classes, grupos e sexos diferentes dos seus como secundários, derivativos, inferiores e subservientes" (KELLNER, 2001, p. 83). Dessa forma, a mídia se constitui em um aparelho responsável pela promoção simbólica de uma nítida separação entre atores "[...] dominantes/dominados e superiores/inferiores, produzindo hierarquias e classificações que servem aos interesses das forças e das elites do poder." (KELLNER, 2001, p. 83)

Levando em conta esse cenário, percebe-se que a mídia consiste em uma espécie de palco por onde desfilam as mais diversas forças da sociedade. Nesse sentido, os meios de comunicação reproduzem os embates entre os setores hegemônicos e contra-hegemônicos ${ }^{7}$ - ou de resistência. A partir disso, procurando estabelecer e verificar as ligações entre os atores envolvidos no campo social, Kellner se utiliza da articulação ${ }^{8}$. Esse conceito traduz, portanto, um ponto importante, ligado ao estudo do processo de organização e produção do discurso dos meios de comunicação em um determinado contexto. Somente assim, por meio de um minucioso

6 Inerente a essa discussão, Thompson (1995) faz menção ao conceito de ideologia, articulando-o às formas como o sentido (significado) serve para estabelecer e sustentar relações (assimétricas) de poder em contextos específicos.

7 Fica clara, aqui, a influência da teoria gramsciana da hegemonia, que prega ser a cultura um autêntico campo de lutas entre diferentes forças. Esta abordagem pressupõe dominação e resistência dos sujeitos sociais em um mesmo sistema. Segundo Souza (1995, p. 26), “[...] a teoria da hegemonia não elimina a prioridade da análise dos conflitos sociais e psicossociais, mas destaca os interlocutores do processo de negociação política no interior das classes sociais, identifica os espaços dessa negociação e, dessa forma, atualiza a análise das modernas interações entre infra-estrutura econômica e superestrutura política, redirecionando a relação entre ideologia e cultura".

8 O pensar crítico resulta em investigar a cultura moderna considerando os aspectos históricos, "[...] suas estruturas constitutivas e principais formas de conduta, sublinhando criticamente as conexões entre relações de poder e discursos com pretensão de verdade." (RÜDIGER, 2001, p. 13) 
exercício de reconstrução histórica dos fatores em jogo, será possível refletir, interpretar e explicar criticamente as questões relativas à cultura da mídia, seus desenvolvimentos e relações com o todo social.

Sabe-se que toda e qualquer produção midiática pressupõe articulações de cunho interno e externo. Assim, são reconhecidas as visões de mundo da empresa de comunicação e a do produtor de informação, ambas baseadas em contextos particulares. Respeitando determinadas regras e aspectos técnicos, considera-se, também, que um texto é constituído dentro de um gênero. Além disso, as relações externas dos produtores de informação e das empresas em que trabalham, em maior ou menor grau, também interferem no produto final - a informação. Tudo isso consiste em um processo complexo. Dessa forma, percebe-se a importância dispensada à mediação e à contextualização dos fatos em uma atividade de investigação crítica, histórica e dialética. Esse tipo de análise facilita $o$ entendimento dos desdobramentos, pois esse método tenta descobrir os "comos" e os "porquês" de uma produção informativa e não somente o "o quê" (senso comum).

Baseado nessas premissas, Kellner (2001) contempla em suas investigações os mais diversos textos midiáticos com o objetivo de elucidar tendências dominantes e de resistência, vislumbrar perspectivas históricas e também analisar a forma como os meios de comunicação agem com vistas a influenciar a identidade dos indivíduos.

Para Kellner (2001), uma leitura crítica dos meios de comunicação também deve se dar de forma política. Reflete o cenário de práticas e discursos da sociedade. Consequentemente, torna-se, também, imprescindível e ao mesmo tempo enriquecedor investigar, de maneira interdisciplinar, os sentidos que a cultura da mídia fabrica e, ainda, quais os movimentos contra-hegemônicos que podem ser originados a partir dessas produções.

Considerando a realidade exposta anteriormente, ao estudar os textos midiáticos sob o prisma das relações entre ideologias, movimentos sociais e o contexto que os envolvem, inspirado pelo sociólogo Robert Wuthnow, Kellner (2001) lança mão de três categorias, a saber: horizonte social, campo discursivo e ação figural. 
O horizonte social diz respeito às múltiplas relações, às práticas e experiências que se desenvolvem dentro do campo social, e que acabam, dessa forma, por contextualizar o local, a época e o cenário em que se dá a produção da cultura da mídia. O campo discursivo contempla todos os elementos (atores hegemônicos e contra-hegemônicos, dominantes e dominados, superiores e inferiores) envolvidos no discurso da mídia. Já a ação figural implica mostrar os desdobramentos sociais de acordo com o horizonte social.

Tendo em vista o cenário apresentado até aqui, nos estudos da cultura da mídia propostos por Kellner (2001), em uma determinada circunstância social e histórica, são analisados o modo de produção da cultura midiática, a mensagem, que é distribuída através de um canal, a recepção ${ }^{9}$ dessa mensagem pelos públicos - também dentro de um contexto específico - e os efeitos do texto nesse público.

Portanto, com base nos pressupostos teórico-metodológicos de Kellner (2001), é preciso contextualizar a época, o cenário em que se dão as relações, as práticas e as experiências sociais. Além disso, é necessário identificar os atores hegemônicos e contra-hegemônicos envolvidos. Somente assim, com base nessa contextualização sócio-histórica, pode-se compreender os desdobramentos, ou seja, as razões que levam a mídia a produzir, em geral, do jeito que produz.

\section{Análises}

Em um cenário globalizante em que a qualidade da informação é, muitas vezes, inversamente proporcional ao índice de audiência, o racional acaba sendo superado com certa frequência pelo espetáculo, pelo conflito e pela fantasia das imagens. Por meio da mídia, vislumbra-se, atualmente, uma realidade na qual o discurso noticioso é substituído por um tipo de "discurso publicitário", ou seja, homogeneizador de identidades ${ }^{10}$,

\footnotetext{
9 Para fins de esclarecimento, a recepção não será trabalhada neste capítulo.

10 Para Hall (2000, p. 109), “[...] é precisamente porque as identidades são construídas dentro e não fora do discurso que nós precisamos compreendê-las como produzidas
} 
estereotipado e mercadológico, a-histórico e sem aprofundamento. Por esses motivos é desprovido de reflexão ${ }^{11}$.

Ocorre, portanto, a primazia do "o quê" sobre o "como" e o "porquê", o que traduz um discurso "carente", superficial e, muitas vezes, "unilateral", que fere a ética jornalística, pois não contempla todos os lados envolvidos em uma determinada questão. Reforçando esse argumento, observa-se que a simplificação de assuntos como a questão dos direitos humanos, por exemplo, é legitimada pela constatação da ausência desses "comos" e "porquês" em determinados momentos da cobertura da mídia. Nesse sentido, Kellner (2001, p. 149) salienta que "[...] se deve prestar atenção ao que fica fora dos textos ideológicos, pois freqüentemente são as exclusões e os silêncios que revelam o projeto ideológico do texto".

A descontextualização e/ou simplificação dos fenômenos estabelece, assim, a noção do inexplicável e sem sentido no imaginário social. Nessa direção, Lage (1998, p. 308) sustenta a hipótese de que "[...] fatos que contrariam versões dominantes, de interesse do sistema de poder, podem ser desqualificados como fenômenos inexplicáveis [...]”. Essa prática de excluir as causas de determinada ação implica a utilização do fait divers de causalidade por meio do subtipo da causa perturbada.

Vivencia-se, então, a cultura do efêmero, o triunfo do descartável. São veiculadas informações superficiais, com carência de substancialidade nos noticiários televisivos, por exemplo. Nas "notícias" de variedades e nos talk shows, contempla-se o apogeu das fofocas e demais atrocidades do mesmo quilate. Nos programas de cunho investigativo, que buscam única e exclusivamente a audiência sob o véu falacioso da justiça, do ajudar pessoas, assiste-se à banalização da violência. É nesse cenário, portanto, que os meios de comunicação fomentam o pensamento rápido e miserável, pobre e acrítico. Além disso, pautas importantes como a questão

em locais históricos e institucionais específicos, no interior de formações e práticas discursivas específicas, por estratégias e iniciativas específicas”.

11 Este tópico remete a uma frase de Habermas (1984, p. 210), quando ele aborda a questão do declínio da esfera pública burguesa afirmando que "o jornalismo crítico é suprimido pelo manipulativo". 
dos Direitos Humanos, entre outras, ocupam um espaço pífio na agenda midiática e, quando ocupam, são apresentados de forma distorcida, como um "problema de polícia", reduzindo a complexidade do tema.

Lembrando Canela (2008), esse cenário reflete um dos dilemas do jornalismo: de um lado, temos uma defesa dos profissionais especializados nas tecnicidades do jornalismo. São os jornalistas que cobrem e divulgam as notícias "corretamente", porém não "vão além". Não há uma adequada problematização das questões conforme abordado anteriormente. De outro lado, existiriam os profissionais preparados para trabalhar conteúdos específicos como, por exemplo, os citados. No entanto, o momento midiático de hoje nos mostra que não é tarefa fácil encontrar um veículo de comunicação que possibilite e/ou tenha condições de oferecer essa possibilidade.

Existem pessoas que creem que essa proposta de atentar para questões mais "desenvolvimentistas" casa melhor com outros processos comunicacionais como, por exemplo, os meios alternativos e a internet. Além do mais, essa possibilidade correria o risco de não trazer um bom retorno financeiro às empresas de comunicação, o que, diga-se de passagem, não estaria nos planos dos seus donos.

Entretanto, a mídia tradicional é peça fundamental para a "[...] consolidação das democracias [...] [e do] desenvolvimento de todas as nações adeptas, ao menos formalmente, deste regime." (CANELA, 2008, p. 11). Segundo Canela (2008, p. 11), os veículos de comunicação deveriam exercer três funções: 1 - contribuir "[...] para o agendamento dos temas prioritários para o desenvolvimento humano [...]" (e não trabalhar essas questões somente quando algo de espetacular acontece); 2 - adquirir um papel central no sentido de colaborar para que os governos, instituições privadas e a sociedade civil também sejam mais responsáveis pela "[...] formulação, execução, monitoramento e avaliação das políticas públicas [...]" (CANELA, 2008, p. 12); 3 - Informar, "[...] de maneira contextualizada, os cidadãos e as cidadãs de tal forma que estes possam participar mais ativamente da vida política, fiscalizando e cobrando a promoção de todos os Direitos Humanos" (CANELA, 2008, p. 12). Quanto mais escla- 
recidos estiverem os membros da sociedade civil, mais condições terão de exercer os seus direitos de cidadãos.

Tal cenário fomenta uma discussão sobre o papel dos produtores da informação. Pode imaginar o dia a dia de um profissional de comunicação encarregado de agendar notícias para o público receptor. Os chamados gatekeepers (filtradores de informações) selecionam o que será tornado de conhecimento público e o que não será. Esse agendamento pode vir a influenciar a sociedade como um todo, ainda que com dinâmicas distintas.

É possível pensar, agora, no contexto particular de um profissional da comunicação, que possui uma determinada visão de mundo, o que the confere um olhar particular sobre as coisas. Esse lugar de fala é tensionado com a visão de mundo da empresa na qual ele - o comunicador trabalha. Nesse sentido, é preciso levar em conta inúmeros fatores que estão presentes na hora de produzir uma informação, a saber: o grau de afinidade da empresa com os atores envolvidos na notícia e as pressões internas - dos superiores dentro da própria empresa em que o profissional atua - e externas - do poder e demais atores hegemônicos da sociedade, dos patrocinadores etc.

No atual estágio da globalização, a mídia respira sob a égide do consumo. Assim, com o objetivo de manter o status quo, o que, é claro, reforça a ideologia das forças hegemônicas, os meios de comunicação acabam lançando mão de várias formas de "violência midiática", as quais acarretam um pensar em perfeita sintonia com os interesses particulares dos veículos de comunicação.

Importante referir nesse aspecto que, no contexto atual, de globalização orientada pelo discurso neoliberal, em que a mídia serve aos interesses dos poderes que detêm as rédeas da economia transnacional, os Direitos Humanos, seus militantes e os movimentos sociais tornam-se obstáculos.

Assim, não são raras as vezes, por exemplo, que esses produtores de informação jornalística divulgam determinado fato, mas, no entanto, direcionam o enfoque da notícia segundo objetivos particulares. Lembrando Lage (1998), essas versões da mídia permitem construir cenários 
convenientes a esta mídia e aos seus protegidos. Quando essa ação ocorre, ela estabelece a ideologia das classes dominantes por meio do poder simbólico.

Uma vez agendada uma pauta importante como a questão dos Direitos Humanos, esta deverá ser fiscalizada pela mídia. Entretanto, percebe-se que inexiste um acompanhamento com relação a isso. Nesse sentido, ter responsabilidade social no jornalismo não significa engajar-se nos movimentos sociais levantando a bandeira de suas causas e fazendo um trabalho panfletário. Tampouco significa manter-se ao lado das forças hegemônicas da sociedade. Significa trânsito e condutas livres. Livres de qualquer força (agente/ator) social. Condutas livres e objetivas, pois o que está em jogo é o serviço prestado ao cidadão.

No entanto, nessa realidade, para atender aos interesses das forças hegemônicas da sociedade, os profissionais da mídia utilizam inúmeras técnicas de manipulação da informação. Todo esse cenário colabora para o triunfo do superficial, do condensado e do acrítico. Ao trabalhar com elementos simplificadores para cobrir questões complexas, ao escolher o fait divers para permear as informações, ao lançar mão da banalização de assuntos cruciais e, portanto, sérios, ao optar pelo "infotenimento"12, o veículo de comunicação desinforma, porém ganha audiência; desinforma, porém atende aos interesses seus e daqueles que protege.

Desinformar, portanto, parece ser, hoje, uma das grandes tendências da mídia tradicional. Como vimos antes, a partir de um deslocamento ideológico de agendamento de questões como os Direitos Humanos, ela presta um desserviço à sociedade. E por que os veículos de comunicação contemplam da maneira como contemplam esses temas? Além das hipóteses aventadas anteriormente, Salomon $(2008$, p. 89$)$ refere que isso acontece porque "[...] há uma preferência pelas notícias que apresentam mudanças dramáticas ou números sensacionais”.

Canellas (2008, p. 105) coloca que, infelizmente, a questão social não é agendada pela imprensa uma vez que o cenário atual é uma mera oportunidade de negócios para grupos cada vez menores. Assim, desapa-

${ }^{12}$ Consiste em uma espécie de fusão da informação com o entretenimento. 
recem noções universais de solidariedade e de bem comum e aparece o argumento cínico que "[...] lamenta as desigualdades apenas para aceitá-las como contrapeso da modernidade".

Embora muitas pautas da agenda social já tenham perdido o ineditismo, isso não retira o "vigor informativo" (CANELLAS, 2008, p. 113) delas. Até porque, considerando esse fator, o que se assiste atualmente não tem nada de inédito. É o mais do mesmo. Somente mudam os atores envolvidos. Portanto, tudo dependerá da maneira como os fatos são tratados pelo repórter. E isso significa atentar, entre outros aspectos, para as questões que estão sendo debatidas neste capítulo.

Por outro lado, percebe-se que quando a mídia cobre essas pautas, geralmente, as faz simplificando a realidade, portanto, desprovidas de elementos suficientes para estimular o senso crítico dos receptores. Quando se aborda esse ponto, se quer dizer que, entre outros fatores, a mídia deve dar voz e vez a todas as partes envolvidas em uma questão. Até mesmo para que a sociedade possa compreender o que realmente está em jogo. Conforme Salomon (2008, p. 86), “[...] a regra é desconfiar sempre. A reportagem será mais honesta e rica quanto maior for a quantidade de pontos de vista levados em consideração". Quando isso não acontece, a sociedade fica impossibilitada de avaliar corretamente uma informação.

Para Almeida (2008, p. 254-255), aumentaram as coberturas midiáticas sobre Direitos Humanos no Brasil. Entretanto, esse avanço "não significa estágio ideal". Nesse sentido, a autora avista alguns problemas: "[...] limitações do processo de produção e transmissão de notícias [...]" (diz respeito às já faladas pressões dos mais variados tipos - internos e externos -, sem contar a questão da rapidez na transmissão de informações); "a inexperiência" (muitas vezes, também, um profissional que tem maior afinidade com outra área acaba escrevendo sobre Direitos Humanos); "[...] a história de vida do profissional [...]" (além de estar atrelado aos ditames da sua empresa e do seu editor, o profissional estará ligado - e isso é inerente - ao seu contexto social, ao seu lugar de fala); e, também, "[...] o fato de a formação em Direitos Humanos ser deficiente no Brasil em todos os níveis educacionais, da escola à universidade [...]" 
(não se discute isso com o devido aprofundamento que o tema merece). (ALMEIDA, 2008, p. 254-255)

$\mathrm{O}$ direito do cidadão à sua existência digna e ao seu desenvolvimento pleno, questões centrais quando a pauta são os Direitos Humanos, muitas vezes, são ignoradas. Para Almeida (2008, p. 260), além disso, constata-se, também, uma "falta de profundidade nas abordagens" midiáticas sobre o tema.

De acordo com Bucci (2008, p. 46), “[...] sem o livre fluxo de informações e opiniões, o regime democrático não funciona, a roda não gira”. Assim, para melhor cumprir seu papel de levar informação ao cidadão, a imprensa precisa fiscalizar - e não proteger - o poder. Fiscalizar no sentido de vigiar. Mas, segundo o autor, "[...] é assim que, na cultura política média do nosso subcontinente, o que tinha de ser óbvio é o oculto. Ou o ocultado.” (BUCCI, 2008, p. 47)

Conforme observa-se ao longo deste capítulo, ao servir de palco para os embates da atualidade, a mídia posiciona-se, portanto, de forma inerente ao poder. Sendo o centro dos acontecimentos do mundo contemporâneo, age como uma autêntica promotora da ideologia das chamadas classes mais favorecidas da sociedade, as forças hegemônicas.

Tal observação provoca outra reflexão: a cultura da mídia pode se dar de duas formas: estimulando a dominação social lançando mão, por vezes, de técnicas que visam a banalização de certos temas e setores da sociedade, enfraquecendo-os, ao mesmo tempo em que pode incentivar a resistência e a luta contra as classes dominantes ao utilizar uma linguagem mais isenta, menos comprometida com o poder.

A cultura da mídia pode constituir um entrave para a democracia quando reproduz discursos reacionários, promovendo o racismo, o preconceito de sexo, idade, classe e outros, mas também pode propiciar o avanço dos interesses dos grupos oprimidos quando ataca coisas como as formas de segregação racial ou sexual, ou quando, pelo menos, as enfraquece com representações mais positivas de raça e sexo. (KELLNER, 2001, p. 13) 
Ora conservadora, ora progressista, a mídia consiste, assim, em um amontoado de contradições.

\section{Conclusões}

Em um contexto globalizante e também cercado de interesses, a mídia tradicional produz informação. Nesse sentido, como se constatou ao longo deste trabalho, os veículos de comunicação adotam inúmeras técnicas discursivas. Entre elas, o fait divers se faz presente seja para descaracterizar um determinado objeto de análise ou para confundir o receptor ou, ainda, privá-lo de dados mais consistentes sobre uma determinada questão.

A partir do momento em que a mídia tradicional lança mão desses artifícios, ela cria obstáculos para a discussão sobre os Direitos Humanos e, concomitantemente, defende/reforça a ideologia das forças hegemônicas da sociedade. Assim, ligados ao poder, os veículos de comunicação não produzem um discurso isento e até quem sabe progressista. Nesse sentido, a questão se impõe: seria esse o verdadeiro papel da mídia?

Acredita-se que a mídia deve dar voz e vez às minorias. Deve dar voz a grupos sociais que lutam por uma vida mais digna. Deve dar voz a assuntos de interesse de todos. Os veículos de comunicação precisam informar sem discriminar e, também, sem ignorar a discussão de fundo relativa aos Direitos Humanos, a de que todo e qualquer cidadão tem direito à sua existência e ao seu desenvolvimento; eles devem utilizar as mais variadas estratégias com a finalidade de alcançar os bens que asseguram a dignidade. E, ao fazer isso, a mídia deve ser profunda, deve problematizar exaustivamente a temática. Não há mais espaço para o superficial. Não há mais espaço para a banalização de questões sérias. Não há mais espaço para a simplificação de assuntos complexos.

Em verdade cumpre referir, de imediato, que a questão da complexidade ou da simplificação da realidade não se esgota na produção da informação, tal redução explode no mundo concreto onde vivem as pessoas com seus dramas. O mundo é complexo, a leitura da mídia é que se faz simplificadora da mesma forma que as respostas encontradas na construção midiática para os problemas da sociedade. Tal processo, portanto, 
insere, no mundo, respostas inadequadas e incapazes de efetivamente dar conta das demandas sociais, mormente, aquelas que se tratou aqui, as quais se referem à garantia dos bens que satisfazem as necessidade humanas.

Mas como essa realidade pode ser transformada? Ou melhor: essa realidade pode ser transformada? Claro que sim. No entanto, a tarefa não é das mais fáceis. Para muitos, talvez, o que foi colocado aqui soou como uma utopia. Por outro lado, acredita-se que vale a pena o esforço.

Em primeiro lugar, é preciso deixar claro que a situação pode ser alterada se houver esforço dos dois lados: da mídia e do próprio receptor. Sim, o receptor, pois ele também é um dos responsáveis - em maior ou menor grau - pela mídia ser mais conservadora e menos progressista. É evidente que não se está eximindo os veículos de comunicação das suas responsabilidades. Apenas sustenta-se que o receptor detém um importante papel nesse processo de transformação das produções midiáticas sobre a questão dos Direitos Humanos.

Primeiramente, no atinente aos profissionais da comunicação, eles deveriam conhecer melhor a problemática que envolve os Direitos $\mathrm{Hu}-$ manos, bem como a sua relação íntima com os movimentos sociais que articulam as tramas que lhes dão sentido e contribuem para sua garantia. Tal aspecto encontra ligação umbilical com a necessidade de um novo perfil dos "donos" dos veículos de comunicação que, ao invés de tratar a informação como mercadoria, eles deveriam encará-la como mais um bem que se traduz indispensável para a realização do homem na sociedade democrática.

Talvez aqui resida um elemento que permita um câmbio significativo na compreensão do papel da mídia, que envolve o reconhecimento do direito à informação como sustentáculo, quem sabe, conditio sine qua non, para a realização dos próprios Direitos Humanos, na medida em que permite que a própria sociedade, a partir do entendimento do mundo social na sua efetiva complexidade, torne-se sujeito transformador do status quo referente aos Direitos Humanos.

Indispensável frisar, resgatando o anteriormente abordado, que a questão da luta pelos Direitos Humanos, não pode ser enfrentada como 
um problema relativo, exclusivamente, ao sistema judicial, esses direitos têm como espaço de conquista, talvez mais importante, o conjunto de relações e de interações sociais. Direitos Humanos não devem ser pensados apenas como um conjunto de normas de caráter nacional e internacional que se efetivam no espaço do litígio judicial, em instâncias formais, mas, sim, e principalmente, algo que se concretiza no seio da sociedade a partir da rearticulação libertatória dos sujeitos sociais.

\section{Referências}

AGUIAR, Odilio Alves. A resistência em Hannah Arendt: da política à ética, da ética a política. In: DUARTE, André; LOPREATO, Christina; MAGALHÃES, Marion Brepohl de (Org.). A banalização da violência: a atualidade do pensamento de Hannah Arendt. Rio de Janeiro: Relume Dumará, 2004.

ALMEIDA, Verônica. A mídia e os direitos humanos. In: CANELA, Guilherme (Org.). Políticas públicas sociais e os desafios para o jornalismo. São Paulo: Cortez Editora, 2008.

BARTHES, Roland. Ensaios críticos. Lisboa: Edições 70, 1971.

BAUMAN, Zygmunt. Globalização: as consequências humanas. Rio de Janeiro: Jorge Zahar Editor, 1999.

BORON, Atílio. Os 'novos Leviatãs' e a polis democrática: neoliberalismo, decomposição estatal e decadência da democracia na América Latina. In: SADER, Emir; GENTILI, Pablo (Org.). Pós-Neoliberalismo: as políticas sociais e o Estado Democrático. Rio de Janeiro: Paz e Terra, 1998.

BUCCI, Eugênio. A imprensa e o dever da liberdade: a responsabilidade social do jornalismo em nossos dias. In: CANELA, Guilherme (Org.). Políticas públicas sociais e os desafíos para o jornalismo. São Paulo: Cortez Editora, 2008.

CANELA, Guilherme. A cobertura jornalística das políticas públicas sociais: elementos para debate. In: CANELA, Guilherme (Org.).

Políticas públicas sociais e os desafios para o jornalismo. São Paulo: Cortez Editora, 2008. 
CANELLAS, Marcelo. Nem imparcial, nem engajado: o repórter como artífice da noticia. In: CANELA, Guilherme (Org.). Políticas públicas sociais e os desafios para o jornalismo. São Paulo: Cortez Editora, 2008. DUSSEL, Enrique. Ética da Libertação na idade da globalização e da exclusão. Petrópolis: Vozes, 2002.

HABERMAS, Jürgen. Mudança estrutural da esfera pública. Rio de Janeiro: Tempo Brasileiro, 1984.

HALL, Stuart. Quem precisa da identidade? In: SILVA, Tomaz Tadeu da. Identidade e diferença: a perspectiva dos estudos culturais. Petrópolis: Vozes, 2000.

HERRERA FLORES, Joaquín. Direitos Humanos, Interculturalidade, e Racionalidade de Resistência. In: WOLKMER, Antônio Carlos. Direitos Humanos e Filosofia Jurídica. Rio de Janeiro: Lumen Juris, 2004.

GALLARDO, Helio. Política e transformación social. Discusión sobre derechos humanos. Quito: Serraj, 2000.

KELLNER, Douglas. A cultura da mídia. São Paulo: EDUSC, 2001.

LAGE, Nilson. Controle da opinião pública: um ensaio sobre a verdade conveniente. Petrópolis: Vozes, 1998.

MORAIS, José Luis Bolzan de. As crises do Estado e da Constituição e a transformação espacial dos Direitos Humanos. Porto Alegre:

Livraria do Advogado, 2002.

RÜDIGER, Francisco. Comunicação e teoria crítica da sociedade. Fundamentos da crítica à indústria cultural em Adorno. Porto Alegre: EDIPUCRS, 2001.

SALOMON, Marta. Além da manada. In: CANELA, Guilherme (Org.). Políticas públicas sociais e os desafios para o jornalismo. São Paulo: Cortez Editora, 2008.

SÁNCHEZ RÚBIO, David. Universalismo de confluencia, Derechos Humanos y procesos de inversión. In: HERRERA FLORES, Joaquín. EI vuelo de Anteo: derechos humanos y crítica de la razón liberal. Bilbao: Desclée de Brouner, 2000. 
SANTOS, Boaventura de Sousa. Crítica de la razón indolente: contra el desperdicio de la experiencia. Volume. I. Bilbao: Declée de brouwer, 2003.

SOUZA, Mauro Wilton de. Recepção e comunicação: a busca do sujeito. In: SOUZA, Mauro Wilton de (Org.). Sujeito, o lado culto do receptor. São Paulo: Brasiliense, 1995.

THOMPSON, John. Ideologia e cultura moderna. Petrópolis, Brasil: Vozes, 1995. 